\title{
L'irréalisable mise en application des dispositifs de recours prévus par la Scottish Poor Law de 1845
}

\section{Christian Auer}

\section{(2) OpenEdition}

\section{Journals}

Édition électronique

URL : https://journals.openedition.org/etudesecossaises/201

DOI : 10.4000/etudesecossaises.201

ISSN : 1969-6337

Éditeur

UGA Éditions/Université Grenoble Alpes

\section{Édition imprimée}

Date de publication : 30 avril 2009

Pagination : 161-170

ISBN : 978-2-84310-138-0

ISSN : 1240-1439

Référence électronique

Christian Auer, «L'irréalisable mise en application des dispositifs de recours prévus par la Scottish Poor Law de 1845 », Études écossaises [En ligne], 12 | 2009, mis en ligne le 30 avril 2010, consulté le 11 avril 2023. URL : http://journals.openedition.org/etudesecossaises/201 ; DOI : https://doi.org/ 10.4000/etudesecossaises.201 


\section{L'irréalisable mise en application des dispositifs de recours prévus par la Scottish Poor Law de 1845}

The Poor relief act is almost a dead letter, and the paupers on some rolls neither get what the law allows them, nor receive their unjust pittance with anything like regularity. On looking into the statistics of pauperism in the northern counties, we meet with some startling facts, which demand inquiry. The average annual allowance to each pauper in this shire (Inverness) is nine shillings, being only one shilling more than in 1741! (Mulock, 1850, p. 57)

Thomas Mulock, qui fut, pendant les deux années qu'il passa dans les Hautes Terres, l'un des journalistes les plus virulents d'Écosse, rédigea ces quelques lignes en 1850, cinq ans après l'adoption de la loi sur les pauvres écossaise. Mulock estimait que la Poor Law n'avait en rien atténué le problème de la pauvreté dans les Hautes Terres; d'après lui, le texte de loi avait même contribué à accroître la précarité de ceux qui ne pouvaient survivre que grâce à la générosité de la société. Ce commentaire, d'une extrême sévérité, nous invite à réfléchir à l'efficacité de la loi, une loi qui avait été adoptée pour prendre en compte les mutations de la société écossaise du XIX ${ }^{\mathrm{e}}$ siècle. Ma réflexion portera sur l'étude des insuffisances ou des faiblesses de la Poor Law, et en particulier des dispositifs qui devaient en théorie permettre aux personnes qui estimaient avoir été injustement privées d'une aide de faire valoir leurs droits, ce qui m'amènera à pénétrer dans l'envers du décor et à m’interroger sur les intentions réelles des législateurs.

La loi sur les pauvres qui fut votée en Écosse en 1845 marqua un tournant décisif dans l'histoire du traitement de la question de la pauvreté dans la mesure où elle transférait la charge de l'aide sociale, qui jusqu'alors avait été le domaine réservé de l'Église, à des structures locales dans lesquelles siégeaient les contribuables. La Poor Law de 1845 créait une structure centrale, le Board of Supervision, et des conseils paroissiaux 
constitués de contribuables élus et investis du pouvoir de décider s’il était nécessaire de recourir à un système de taxation pour alimenter le fonds d'aide aux pauvres de la paroisse, si les fonds collectés par les moyens traditionnels devaient se révéler insuffisants. Il est légitime de se poser la question de la faisabilité d'une telle disposition : comment en effet pouvait-on concevoir qu'un conseil paroissial décide de lever des impôts supplémentaires, alors qu'aucune clause dans la loi ne l'y obligeait et que la charge fiscale existante était bien souvent considérée comme trop importante ? À la satisfaction des grands propriétaires, aucune disposition dans la loi ne contraignait les conseils paroissiaux à venir en aide aux pauvres valides :

And be it enacted, That [...] all assessments imposed and levied for the relief of the poor shall extend and be applicable to the relief of occasional as well as permanent poor: Provided always, that nothing herein contained shall be held to confer a right to demand relief on able bodied persons out of employment ${ }^{1}$.

Certains historiens estiment que cette loi fut révolutionnaire dans la mesure où elle transférait la charge de l'aide sociale à des structures (les parochial boards) dans lesquelles siégeaient des contribuables (voir Duchein, 1998, p. 418). Pendant des siècles en effet le poids principal de l'aide aux pauvres avait reposé sur les épaules des conseils d'église dont les fonds provenaient de collectes effectuées lors des offices, de dons ou d'amendes infligées aux personnes qui enfreignaient les règles ecclésiastiques. Plutôt que de « révolution », je préfèrerais pour ma part parler de « réforme », car la loi ne modifiait en rien le principe de base qui régissait le dispositif d'aide aux pauvres en Écosse depuis le $x{ }^{\mathrm{e}}$ siècle, le texte réaffirmant que seules les personnes non valides en raison de leur âge ou de leur état de santé pouvaient bénéficier d'une aide de la communauté. Comme le remarque fort justement l'auteur d'un ouvrage sur la loi sur les pauvres, « the basic tenets of the Scottish poor relief were upheld. [...] Allowances continued to be viewed as supplementary in nature. Little was gained by the poor in Scotland. » (Cage, 1981, p. 150)

Pour ce qui est des dispositifs d'appel, la loi considérait deux cas de figure : si une personne estimait qu'elle était injustement privée d'une aide, elle avait la possibilité de faire appel auprès du shérif du comté et si une personne inscrite sur la liste officielle des pauvres de la paroisse estimait que son allocation était insuffisante, elle devait contacter l'inspecteur des pauvres. Il convient d'emblée de remarquer que certains conseils paroissiaux regroupaient des hameaux qui s'étendaient sur des

1. «The Poor Law Amendment Bill of Scotland », The Inverness fournal, 2 mai 1845. 
zones géographiques très vastes. De surcroît, les moyens de communication en ce milieu de $\mathrm{XIX}^{\mathrm{e}}$ siècle étaient encore très peu développés dans les Highlands ; il est donc aisé d'imaginer les difficultés auxquelles était confronté le paysan qui souhaitait contacter le shérif du comté. Lors d'une séance parlementaire, le député libéral de St Andrews, Edward Ellice, donna l'exemple d'un habitant de l'île de Barra qui dut parcourir une distance totale de près de soixante kilomètres pour pouvoir enfin contacter la personne qui était censée recevoir sa plainte. Ellice en déduisait que cette disposition était inapplicable : «In very many instances the appeal to the Sheriff was no appeal at all ${ }^{2} »$. Le shérif délégué de l'île de Lewis, quant à lui, fit état des pressions que subissaient les personnes qui osaient contester les décisions des conseils paroissiaux :

I am informed that a great many who have a legal title to relief in the remote parishes have not obtained it, and that they cannot come here to complain because of the distance, their inability to travel, and want of food, and also because the relations of a few who did come from South Uist were threatened by the authorities with the displeasure of the proprietor for having come. They cannot write themselves, and those who can write are afraid to write for them ${ }^{3}$.

Selon les termes de la deuxième possibilité d'appel, une personne qui estimait que son allocation était insuffisante devait adresser un formulaire au Board of Supervision ; la structure centrale prenait alors l'avis du conseil paroissial concerné, la structure même qui avait procédé au recrutement de l'inspecteur. Edward Ellice remarqua qu'une telle démarche ne pouvait qu'être vouée à l'échec :

Under such circumstances a poor illiterate pauper could not have much chance of success in his appeal against the statements of a well-educated Inspector, supported as he was sure to be by his board of ratepayers to whom he owed his situation ${ }^{4}$.

Il convient de se souvenir que le taux d'alphabétisation dans les Highlands était bien inférieur à celui des autres régions d'Écosse et que de surcroît la majorité des paysans était gaélophone : la rédaction du moindre document officiel représentait donc une démarche des plus ardues. J'ajouterais qu'il est permis de s'interroger sur l'indépendance et l'objectivité des inspecteurs des conseils paroissiaux alors que les fonds qui

2. «Imperial Parliament, House of Commons », The Inverness Courier, 10 mai 1855.

3. "Barra, South Uist and Benbecula, Highland Estates of Colonel Gordon of Cluny ", The Inverness Courier, 17 mars 1847.

4. «Administration of the Poor Law », The Inverness Advertiser, 14 février 1854. 
étaient à leur disposition provenaient en partie de l'impôt dont s'étaient acquittés les propriétaires des domaines qui les employaient. Bien souvent l'inspecteur auquel était censé s'adresser le plaignant exerçait d'autres fonctions au sein de la communauté, ce qui rendait la procédure d'autant plus aléatoire. Le problème du cumul des fonctions fut clairement identifié par Robert Somers, un journaliste qui se rendit dans les Highlands en automne 1847. Somers consigna ses observations dans une trentaine de lettres qui furent publiées dans le North British Daily Mail de Glasgow. Il dressa le portrait d'une région et d'une société en proie à une mutation économique sans précédent. Contrairement à de nombreux autres observateurs, qui exprimaient des opinions le plus souvent empreintes d'une subjectivité exacerbée, Somers tenta de porter un regard mesuré sur la société des Highlands, même si par moments, comme en attestent les lignes suivantes, il se laissa entraîner sur la voie de l'ethnocentrisme :

The Highlands and the Highlanders are not quite so far advanced in learning yet as to be able to finish their education without the aid of a master; and to let alone is with them only another phrase for leaving to destruction. (Somers, (1848), 1977, p. 45)

Somers se montra à la fois sévère à l'encontre des propriétaires accusés d'avoir laissé leurs paysans à l'abandon, et critique à l'encontre des Highlanders, auxquels il reprochait leur oisiveté et leur paresse : «The Highland people spend a great part of their time in idleness. » (Somers, p. 169) Somers identifia avec une certaine acuité le problème du cumul des fonctions des personnes placées en position d'autorité :

In every part of the island you find the most multifarious and incongruous professions conjoined in the same person [...] the system is injurious in every respect. It divides society into two extreme classes, one of which it exalts and the other it humiliates. (Somers, p. 109)

Somers donna l'exemple d'un domaine situé dans l'île de Skye dans lequel l'inspecteur des pauvres n'était autre que le régisseur du propriétaire. Plus étrange encore, certains responsables d'exploitations ovines, ceux-là mêmes qui étaient à l'origine des déplacements de population de la paysannerie, exerçaient également les fonctions d'inspecteurs des pauvres.

Le pauvre qui s'estimait victime du système se trouvait donc confronté à toute une série de difficultés, d'ordre culturel, linguistique, géographique, social et légal. En dépit de ces innombrables obstacles, dans certains cas, certes extrêmement rares, les autorités donnèrent satisfaction aux plaignants. Comme l'atteste l'extrait de l'article suivant, publié par le Inverness Courier en novembre 1846, la presse conservatrice se faisait un plaisir de rendre compte des décisions de justice qui semblaient prouver 
l'efficacité des mesures mises en place par la loi : «It [the judgment] decides, among minor points, that the right to a dwelling-house, in the case of homeless paupers, is included in the right to parochial relief ${ }^{5}$ ». En janvier 1847, le Inverness fournal se félicita d'une décision qui avait été prise en faveur d'un plaignant, un paysan veuf, âgé de soixante ans et père de trois enfants, qui s'était vu refuser l'allocation qu'il sollicitait :

The publication of the Sheriff's clear and conclusive deliverance at the present time may do good both to Parochial Boards and to paupers - to the former, in showing them their duty, and preventing them from incurring expense, in endeavouring the just claims of the poor; to the latter, in facilitating their obtaining that relief which their circumstances render necessary, and which the law of the country mercifully and wisely affords them ${ }^{6}$.

Il suffit d'examiner les données statistiques communiquées par les conseils paroissiaux pour constater à quel point les possibilités d'appel n'étaient que théoriques. Je prendrai deux exemples, l'un au niveau local, l'autre au niveau régional. Le rapport de septembre 1847 du conseil paroissial d'Inverness indiquait que sur une période de six mois quatre demandes d'appel avaient été formulées dont deux seulement avaient été acceptées. Si l'on prend en compte le nombre total de pauvres officiellement recensés par le conseil paroissial d'Inverness, soit près de huit cents personnes, force est de constater que rares étaient ceux qui parvenaient à formuler une demande de recours et encore plus rares ceux qui obtenaient gain de cause ${ }^{7}$. Le chiffrage des demandes de recours communiqués par le Board of Supervision pour les années 1847 et 1848 apportent la confirmation irréfutable qu'il était presque impossible d'obtenir gain de cause en cas de dépôt d'une plainte :

Of the 707 complaints [of insufficient relief in 1847], there was refused or withdrawn 420; and in 279 cases, the ground of complaint was removed. Of the 437 complaints in 1848, there were refused or withdrawn 248, and in 179 cases, the ground of complaint was removed ${ }^{8}$.

Si l'on additionne les plaintes déposées au cours de ces deux années, on parvient à un total de près de mille cent cinquante sur lesquelles moins d'une vingtaine avait été acceptée, ce qui représente un pourcentage dérisoire de moins de $2 \%$. La forte réduction du nombre de plaintes entre

5. «Important Poor Law Decision », The Inverness Courier, 25 novembre 1846.

6. «Fort William - Poor Law Decision », The Inverness fournal, $1^{\text {er }}$ janvier 1847.

7. «Report of the Acting Committee of the Parochial Board of Inverness ", The Inverness fournal, 3 septembre 1847.

8. «Scottish Poor Law », The Inverness Courier, 9 août 1849. 
1847 et 1848 ne saurait être interprétée comme un signe de la diminution de la pauvreté dans sa globalité ; il semblerait plutôt que tout ait été fait pour dissuader les plaignants potentiels d'aller jusqu'au bout d'une démarche qui n'avait que fort peu de chances d'aboutir.

Les dispositifs mis en place par la loi de 1845 donnèrent lieu à des analyses et des commentaires divergents. Les enquêtes menées par les autorités démontraient que le système fonctionnait de façon satisfaisante. Ainsi, en juin 1850, un inspecteur du conseil paroissial d'Inverness présenta un rapport dans lequel il rendait compte de sa visite dans certains des villages les plus difficiles d'accès du comté. Il nota avec grande satisfaction que les personnes qu'il avait rencontrées étaient toutes en très bonne santé, y compris les plus âgées d'entre elles : «On the whole, the paupers are very thankful for what they receive from the board ${ }^{9}$ ». John MacNeill, le président du Board of Supervision, constata, lors d'une mission d'enquête effectuée dans les Hébrides en 1851, que les pauvres vivaient dans des conditions tout à fait acceptables ${ }^{10}$. Le nombre très élevé de personnes sans emploi l'incitait à penser que la misère était devenue pérenne et qu'il fallait donc trouver une solution qui soit en mesure de résoudre le problème de façon définitive : le salut ne viendrait que de la mise en place d'un vaste programme d'émigration. La presse radicale des Highlands, quant à elle, ne cessa de vitupérer contre l'iniquité de la Poor Law. Le Northern Ensign de Wick revendiquait la mise en place d'un système qui puisse prendre en compte les pauvres valides, une catégorie qui avait considérablement cru en nombre depuis les mauvaises récoltes des années 1847-1850 : «An able bodied Poor Law should be introduced, and that with so an effective and complete a machinery, as to render it impossible for the heritors and others to avoid feeling his crushing weight ${ }^{11}$ ». Le journal critiquait également l'inefficacité des structures locales et régionale :

The Board of Supervision, as well as the Parochial Boards, having for a long time turned a deaf ear to the complaints of the poor, public opinion must be called in order to check the conduct of the Poor Law Boards and of those Poor Law officials in these remote districts ${ }^{12}$.

9. «Invernessshire, Parochial board, Half Yearly Board », The Inverness Advertiser, 25 juin 1850. 10. Entre le 3 février et le 17 avril 1851, Sir John MacNeill visita vingt-sept paroisses, la plupart d'entre elles situées dans l'île de Lewis.

11. "Shameful Treatment of the Poor in the West Highlands ", The Northern Ensign, 2 mars 1854. 12. Ibid. 
D'autres observateurs, comme Robert Somers, attribuaient l'inefficacité de la Poor Law à la difficulté de la mise en œuvre des dispositifs de recours :

The Highland parochial boards, generally speaking, manifest the most determined hostility to the legal claims of the poor; and the defect of the present state of the law is, that it leaves the poor entirely powerless to assert their rights in opposition to their local oppressors. [The law] handed them over to the tender mercies of a Central Board of Supervision, sitting in secret, hearing their complaints only upon schedules, refusing them a right of reply to the allegations of hostile inspectors, and giving no reasons for its decisions, though involving questions of life or death to the poor. (Somers, p. 172)

Somers proposait que les demandes de recours soient adressées non pas au Board of Supervision mais à la Haute Cour de Justice, ce qui permettrait au plaignant d'obtenir des décisions prises en toute indépendance. Certains parlementaires, convaincus, eux aussi, que la loi présentait de graves insuffisances, tentèrent de proposer des amendements qui permettraient une réelle prise en charge des laissés pour compte de la nouvelle donne économique. Pour Edward Ellice, le député de St Andrews, les ambiguités de loi avaient permis aux propriétaires de se décharger de leurs responsabilités envers les pauvres de leurs domaines :

I stated my opinion that [...] in the remote parishes of the Western Highlands the obligations of the Poor-law, both in the spirit and the letter of the act, were disregarded; that public observation, not penetrating into these comparatively inaccessible districts, except on rare and extraordinary occasions, and the means of redress afforded by the law being so little, if at all, understood by the poor inhabitants generally, or, where known, being opposed by so many local obstacles, and difficult of access, the humane intentions of the Legislature were entirely defeated ${ }^{13}$.

En 1854, Edward Ellice présenta un projet de loi dont l'une des clauses essentielles concernait le statut et le rôle des inspecteurs. Ellice proposait que les inspecteurs soient nommés par le ministère de l'Intérieur, qu'ils aient l'obligation de rendre visite aux pauvres au moins une fois par an et de s'adjoindre les services de traducteurs assermentés au cas où les personnes concernées ne s'exprimeraient qu'en gaélique. Ellice retira son projet de loi car il obtint l'assurance du gouvernement qu'une réflexion approfondie allait être menée afin de déterminer quelles étaient les mesures à prendre pour améliorer le fonctionnement de la loi de 1845.

13. "Administration of the Poor Law in the Highlands, From The Scotsman », The Inverness Courier, 11 mai 1854. 
Arrêtons-nous à présent quelques instants sur les « intentions bienveillantes » du législateur, pour reprendre les termes mêmes d'Edward Ellice. Cette remarque pose la question essentielle de la place de la Poor Law de 1845 dans l'idéologie des classes dominantes de la société victorienne. Rappelons brièvement que la pauvreté était perçue comme un fléau qu'il s'agissait de combattre avec la plus grande énergie et que le pauvre était considéré comme un obstacle par les tenants de l'orthodoxie économique. La société dans son ensemble n'avait que le plus profond mépris pour les pauvres valides qui ne travaillaient pas. Voici ce que pensait la commission qui fut chargée d'étudier le fonctionnement de la loi sur les pauvres ${ }^{14}$ : «If a man will not work neither should he eat. The over-looking of this salutary maxim [...] has been proved by experience to be productive of the most serious evils in the social system. » (Cité dans Cage, p. 141) Il était impensable que le pauvre puisse bénéficier des mêmes conditions de vie que le travailleur, une opinion que partageaient les autorités religieuses et politiques ainsi que les fonctionnaires chargés de diriger et de gérer les différentes structures qui furent créées pour lutter contre la pauvreté dans les Highlands et dans les Hébrides. Thomas Chalmers, l'un des principaux responsables de la rupture de la Kirk en 1843, s'opposait à toute forme de charité pour les pauvres valides. Chalmers estimait que le pauvre valide qui percevait une aide de la collectivité perdait de son indépendance et vivait au détriment de ceux qui avaient réellement besoin du soutien de la société. Charles Trevelyan, le haut fonctionnaire du ministère des Finances qui fut chargé de la direction des opérations d'aide en faveur des habitants des Highlands en 1846-1847, indiqua explicitement que l'assistance aux pauvres devait être encadrée avec la plus grande vigilance :

Next to allow the people to die of hunger, the greatest evil that could happen would be their being habituated to depend upon public charity. The object to be arrived at, therefore, is to prevent the assistance given from being productive of idleness ${ }^{15}$.

La plupart des journaux écossais tenait un discours similaire. Voici par exemple ce qu'écrivit le Inverness Courier en août 1845 : « No soundminded person will venture to assert that the pauper should be better provided for than those who support themselves by their own industry - who

14. La commission fut constituée en 1844.

15. National Archives of Scotland, Highland Destitution, 6/2, Uncorrected Correspondence Relating to the Measures Adopted for the Relief of the Distress in Scotland, Second Part from February to September 1847, lettre de Trevelyan à Baird, 19 mars 1847. 
contribute, indeed, also to support that very pauper ${ }^{16} »$. Le Edinburgh Evening Post ne disait pas autre chose quand il remarquait que « if the labouring man finds that he gets nearly as much by sitting all day at the fireside, with his hands folded before him, as he can make by the hardest work, he will naturally choose the easier life ${ }^{17} »$. Comment pouvait-on imaginer que le pauvre soit autorisé à vivre dans des conditions identiques à celui qui, par son travail, jouait pleinement son rôle au sein de la société et participait à la marche en avant vers le progrès ?

The first and most essential of all conditions, a principle which we find universally admitted, even by those whose practice is at variance with it, is that his [the pauper's] situation on the whole shall not be made really or apparently so eligible as the situation of the independent labourer of the lowest class. (Cité dans Frison, 2005, p. 210-211)

Ces quelques lignes, extraites de la conclusion du rapport sur lequel s'étaient basés les parlementaires pour rédiger la loi anglaise de 1834 sur les pauvres, attestent des profondes similitudes idéologiques qui servirent de cadre de référence à l'élaboration des lois anglaise et écossaise sur les pauvres. Le pauvre des Hautes Terres d'Écosse était victime d'une double discrimination: en tant que pauvre tout d'abord, puis ensuite en tant que pauvre d'une région perçue comme représentant un obstacle sur la voie du progrès et du développement économiques. Certains n'allaient-ils pas jusqu'à considérer que la pauvreté était un des éléments essentiels, je serais presque tenté de dire constitutifs, de la société des Highlands?

The stranger comes direct from well-fed England, and is smitten with charitable horror at the scanty food and black homely dwellings of the Scottish Highlanders - not reflecting that this to them is "nature" 18 .

La Poor Law de 1845 s'intégrait donc parfaitement dans le courant de pensée victorien qui vénérait par-dessus tout l'éthique du travail. Souvenons-nous, par exemple, de ce qu'écrivit Thomas Carlyle, dans Past and Present :

There is a perennial nobleness, and even sacredness, in Work [..] there is always hope in a man that actually and earnestly works; in Idleness alone is there perpetual despair [...] Blessed is he who has found his work; let him ask no other blessedness. He has a work, a life-purpose; he has found it, and will follow it. (Carlyle, 1843, p. 197-198).

16. «Scottish Poor - Rural Improvements », The Inverness Courier, 20 août 1845.

17. «Pauperism in Scotland, From The Edinburgh Evening Post», The Inverness fournal, 31 mars 1848.

18. « Scottish Poor - Rural Improvements », The Inverness Courier, 20 août 1845. 
Dans ce contexte, comment peut-on interpréter et analyser les intentions bienveillantes du législateur? Il me semble qu'il serait difficile de contester que la vocation première de la Poor Law fut de persuader les pauvres que l'aide qu'on leur accordait n'avait qu'un caractère exceptionnel et transitoire, qu'elle n'était qu'une étape destinée à leur faire redécouvrir les vertus de l'indépendance et de les réinsérer dans le monde du travail. Le législateur avait certes accordé un pouvoir aux pauvres qui s'estimaient injustement privés de l'aide de la communauté mais ce pouvoir théorique se délitait et se désagrégeait au contact de la réalité des faits. Les « faiblesses » de la Poor Law reflètent les idées et les préjugés, en un mot l'idéologie, des couches dirigeantes de la société britannique. Les insuffisances de la loi ne doivent-elles pas plutôt être interprétées comme l'expression d'une volonté délibérée, d'une stratégie mûrement réfléchie qui visaient un double objectif : inciter les pauvres en rupture de moralité à retrouver les vertus et les préceptes de la morale et réduire au minimum la charge financière qui pesait sur la collectivité ? Comme le démontrent ses illusoires possibilités de recours, la Poor Law de 1845 fut avant tout une loi destinée à lutter, non pas contre la pauvreté, mais contre les pauvres.

\section{Références bibliographiques}

The Inverness Advertiser

The Inverness Courier

The Inverness fournal

The Northern Ensign

Cage R. A., The Scottish Poor Law, Édimbourg, Scottish Academic Press, 1981.

Carlyle T., Past and Present and Chartism, New York, George Putnam, 1848.

Duchein M., Histoire de l'Écosse, Paris, Fayard, 1998.

Frison D., Civilisation Britannique, Documents Constitutionnels, Paris, Ellipses, 2005.

Mulock T., The Western Highlands and Islands of Scotland, Socially considered, with Reference to Proprietors and People: Being a series of Contributions to the Periodical Press, Édimbourg, Menzies, 1850.

Somers R., Letters from the Highlands, After the Great Potato Famine of 1846 (Glasgow, 1848), Inverness, Melvens Bookshop Ltd., 1977. 